

\title{
Temporal and spatial changes of the submarine Cretaceous paleoslope in Northern Tunisia, inferred from slump folds analysis
}

Chahreddine Naji, Mohamed Gharbi, Zayneb Amri, Amara Masrouhi, Olivier Bellier

\section{To cite this version:}

Chahreddine Naji, Mohamed Gharbi, Zayneb Amri, Amara Masrouhi, Olivier Bellier. Temporal and spatial changes of the submarine Cretaceous paleoslope in Northern Tunisia, inferred from slump folds analysis. Proceedings of the Geologists' Association, 2018, 129 (1), pp.40-56. 10.1016/j.pgeola.2017.10.006 . hal-01882007

\section{HAL Id: hal-01882007 https://hal.science/hal-01882007}

Submitted on 26 Apr 2019

HAL is a multi-disciplinary open access archive for the deposit and dissemination of scientific research documents, whether they are published or not. The documents may come from teaching and research institutions in France or abroad, or from public or private research centers.
L'archive ouverte pluridisciplinaire HAL, est destinée au dépôt et à la diffusion de documents scientifiques de niveau recherche, publiés ou non, émanant des établissements d'enseignement et de recherche français ou étrangers, des laboratoires publics ou privés. 


\section{Temporal and spatial changes of the submarine Cretaceous paleoslope in Northern Tunisia, inferred from Slump folds analysis}

Chahreddine NAJI ${ }^{a, b}$, Mohamed GHARBI ${ }^{a}$, Zayneb AMRI ${ }^{a, b}$, Amara MASROUHI $^{c,}{ }^{*}$, Olivier BELLIER ${ }^{d}$

${ }^{a}$ Geo-resources Laboratory, Centre de Recherches et des Technologies des Eaux de Borj Cedria, Soliman, Tunisia

${ }^{b}$ Université de Carthage, Faculté des Sciences de Bizerte, Bizerte, Tunisia

${ }^{c}$ King Abdulaziz University, Faculty of Earth Sciences, Geo-exploration techniques Department, Saudi Arabia

${ }^{d}$ Aix Marseille Univ, CNRS, IRD, Coll France, CEREGE, Aix-en-Provence, France

*corresponding author. amara.masrouhi@fsg.rnu.tn

\section{ABSTRACT}

This paper presents the first comprehensive, non-exhaustive, study of the genetic relationship between slump folds and the synsedimentary paleoslope during Cretaceous time in northern Tunisia. Slump folds occur mainly in the Cretaceous marl-dominated lithofacies, which exposes numerous slump folds structures. In addition, fault kinematic analysis is conducted to define the paleostress fields and the stress states characterizing the Cretaceous extension that triggers soft-sediment deformation and slumping. The MAM and the APM methods are used to deduce the paleoslope in several localities. The calculated values of paleoslope trend derived from MAM and APM methods precise the variation of the paleoslope trend during Cretaceous times in northern Tunisia. This paleoslope is $\sim$ NW-dipping during Berriasian, $\sim \mathrm{SSW}$-dipping during Valanginian, $\sim \mathrm{NW}$-dipping during the Barremian and $\sim \mathrm{N}$ - to $\sim$ NNE or $\sim S$ - to $\sim S S W$-dipping during Aptian-Albian period. The results of the back-tilted fault diagram show a $\sim$ North to $\sim$ Northeast-trending tectonics extension. The back-tilting of Cenomanian slump axis and poles of axial planes (MAM and APM methods) give close results with $\sim$ Southward or $\sim$ Northwarddipping paleoslope. The restored fault diagrams show $\sim$ North to $\sim$ Northeast-trending extension during Cenomanian times. Coniacian-Santonian marls deposits seal all the gravity-driven deformation structures. North Tunisian area exposes evidences for abundant soft-sediment deformation and slumping atop a northward facing submarine slope, which was probably dominant from the Early Cretaceous to Santonian with $\sim$ North-South tectonic extension related to the Southern Tethyan rifted continental margin evolution.

Keywords: Cretaceous; submarine paleoslope; slump folds; Tunisia 


\section{Introduction}

Slumps folds, generated within unlithified sediments atop existent slope, form one of the most remarkable features indicative of slope and basin-floor settings. Submarine slumping characterizes the sediment-shape in both active and passive margins context (Woodcock, 1979, Strachan and Alsop, 2006; Alsop and Marco, 2014; Sharman et al., 2015). In passive margin framework, the driving force of such structures is acknowledged to be the gravitational instability over a submarine slope. During and/or after sedimentation, and before complete lithification, sediments moving downward (naturally from continental shelf to basin) in successive depositional events. Subsequently, Slump horizons are classified as primary structures that reflect paleoslope direction. Geoscientists have developed several techniques, from slump folds, to deduce the direction of the paleoslope of both recent and ancient margins (Heifetza et al., 2005; Strachan, 2008; Peel, 2014). North Tunisian area (Fig. 1) exposes evidences for abundant soft-sediment deformation and slumping that characterized the evolution of the Southern Tethyan rifted continental margin. However, to our knowledge, studies of the gravitydriven deformational structures are still insufficiently characterized or even absents in this region.

By the evaluation and analysis of slump folds and associated soft-sediment structures, many paleoslope and paleogeographical reconstructions were tested worldwide (Hansen, 1971; Woodcock, 1979; Debacker et al., 2009). Several techniques have been developed for the deduction of the direction of the paleoslope from slump folds. Jones (1940) was the first who quantified the application of this idea using the Mean Axis Method (MAM) based on the correlation of mean slump fold axis with paleoslope strike in estimates of paleoslope direction (Fig. 2). Alternative method thereafter designated by Hansen $(1965,1967)$ used the Separation Arc Method (SAM) is based on determining the paleoslope direction from the bisector of a separation Arc named Separation Arc Method. Woodcock (1979) reviewed these methods and suggested a procedure for determining paleoslope directions which reflects the respective strengths of the two methods. More recently, other studies have focused on the study of slump folds and described other methods to estimate the paleoslope direction from these structures (Bradley and Hanson, 1998; Strachan and Alsop, 2006; Strachan, 2008; Debacker and Meester, 2009; Alsop and Marco, 2011, 2012a, b, 2013, 2014; Debacker, 2012; Yong and al.,2013; Sharman, 2014). These methods use well-determined parameters of slumps such as slump fold axis, axial plane, interlimb angle...etc. Alsop and Marco (2012a) reviewed the methods (i.e. fold facing directions, mean axis method -MAM-, mean axial plane strike method -MAPS-, mean axialplanar dip method -MAD-, separation arc method -SAM-, axial planar intersection method -AIM-, estimating the paleoslope direction from slumps folds structures (Fig. 2) with the contemporary understanding. Authors gave a detailed description highlighting similarities and differences between 
methods to deduce the direction of paleoslope from slumps folds (for more detail see Alsop and Marco, 2012a).

The analysis of slump folds and faults data together with sequences correlation are used in this study to evaluate Cretaceous soft-sediment deformation in north Tunisia. This work is the first comprehensive, non-exhaustive, study in north Tunisia applying known techniques to deduce paleoslope of the Cretaceous basin based on the slump folds analysis. The work intention is to present a structural contribution, via syndepositional deformation, to the debate about the basin paleogeography which is usually studied in this basin by stratigraphy and/or sedimentology. The northeast Tunisia exposes evidences for abundant soft sediment deformation features atop a synsedimentary Cretaceous submarine slope. This study presents the compilation of 100 slump folds collected along $54 \mathrm{~km}$ section from the Sidi Salem in the Southeast to the Jebel Boulahouadjeb in the Northwest.

\section{Geological setting}

Northern Tunisia is a part of the northern edge of the African plate and represents the eastern part of the Atlas System. The Atlas fold-and-thrust belt, extending from Morocco to Tunisia, is itself a part of the alpine chain of Africa named "the Maghrebides belt" which is related to the Alpine orogeny. Tunisia makes the eastern frontier of the Maghrebides belt. Except its northerly edge which corresponds to the Numidian range, the Northern Tunisian Atlas (Fig. 1) is divided into two distinguished structural units: (1) First, a major southeastward major thrusted unit called Teboursouk thrust unit, which corresponds to the front of the Alpine Range and shows a thick Aptian-Albian sequences. This area exhibits also numerous outcropping salt structures belonging to the northeastern Maghreb salt province (Masrouhi et al, 2013; Jaillard et al., 2013), (2) second, the Zaghouan-Ressas unit, acknowledged by last reviews to be the front of the Northern Tunisian Alpine Range. The present Zaghouan Thrust Fault corresponds to an inverted inherited fault, which during Mesozoic time, makes a paleogeographic line dividing a relatively shallow platform to the south, with a condensed Aptian section from a deep basin in the north (Morgan et al., 1998; Soua, 2016) with a thick Aptian-Albian section (Chihaoui et al., 2010).

The present-day fold-and-thrust belt in northern Tunisia is the result of the Meso-Cenozoic geological evolution of the northern African margin, which can be summarized in two main periods. The first is the Mesozoic rifting, highlighted from Late Permian(?) to the Early Cretaceous (Guiraud, 1998). This rifting is related to the Tethyan and Atlantic Oceans opening. Early Triassic salt basins were shaped, overall Tunisia, during the earlier stage of this evolution (Soussi et al., 2017). The extensional setting prevailed during Jurassic and Early Cretaceous (Boughdiri et al., 2007; Souquet et al., 1997; Masrouhi and Koyi, 2012; Dhahri and Boukadi, 2017), led to the opening of Central Atlantic. Late reviews (e.g. 
Guiraud et al., 2005; Gharbi et al., 2015) demonstrate a paleogeographic differentiation of the continental platform, which is accompanied in some localities by an associated volcanic and halokinetic activity (Mattoussi Kort et al., 2009; Dhahri and Boukadi, 2017, Jaillard et al., 2017). A major synsedimentary normal faulting delivering a general tilted blocks geometry, for which the AptianAlbian ages are perceived to have the most extreme extensional related-structures time of the south Tethyan edge in North Tunisia (Souquet et al, 1997; Gharbi et al., 2013; Masrouhi et al., 2014b). Likewise, related Cretaceous salt movement confirms an hyperactive extension, thick and/or thinskinned tectonic extension (Masrouhi et al., 2014a). The frequent NW- to- WNW-trending faults, related to N-to-NE-trending extension, are likely in control of an irregular sea-floor highlighted by significant thickness and/or facies changes during Cretaceous (Dhahri and Boukadi, 2017, Jaillard et al., 2017). The associated series show abundant slumps and syntectonic sequences (Gharbi et al., 2013). This margin is generally acknowledged, by all accounts of past reviews, to exposes a general NWdipping submarine slope (Souquet et al., 1997; Masrouhi et al., 2013).

The second main period, started since Late Cretaceous (approximately Campanian-Maastrichtian), causes a basin positive inversion related to the Africa and Eurasia plate convergence (Guiraud and Bosworth, 1997; Gharbi et al., 2015). Two markedly compressional events affected the Atlas belt: the Atlassic mid-to-late Eocene contractional event (Frizon De Lamotte et al., 2002; Masrouhi et al., 2008; Dhahri and Boukadi, 2010) causes significant inversion of the basins, followed by the Miocene Alpine event which is the major orogenic contractional event that propagates deformation southward and responsible for the present-day NE-trending complex northern Tunisia Fold-and-Thrust belt (Chihi, 1992; Dhahri and Boukadi, 2010; Gharbi et al., 2014). The Mesozoic basins of northern Tunisia are geometrically disturbed after having undergone the Neogene compressional tectonics that affected the northern African margin. This makes difficult the analysis of soft-sediment deformation and slumping that occurred previously to the tectonic inversion of this area.

\section{Tectono-sedimentary data}

To date and to precise/approximate the successive depositional events, detailed new key-facies description is used in this study, based on micropaleontological existent data (for more details on micropaleontological data, see Turki, 1988; El Ouardi, 1996; Rami, 1998; Masrouhi, 2006; Ben Fadhel et al., 2011; El khazri et al., 2013). Correlation of Cretaceous sequences is also significant because the facies and thickness of sediments are greatly affected by the synsedimentary faults activity of the faults bordering the adjacent tectonic blocks.

\subsection{Lithostratigraphy and correlation of measured sections}

The section of Jebel Oust (Fig. 3) is the reference type-section in northern Tunisia lower Cretaceous basin sequences (Souquet et al., 1997). It exposes a $2600 \mathrm{~m}$ thick Barremian-Aptian sequences. 
According to Souquet et al. (1997), the Tithonian-Berriasian is marked by debris-flow and mud-flow deposits. The Berriasian p.p. is composed of greenish muds and thin-bedded sandstones and siltstones. The Valanginian-Hauterivian unit is made by a siliciclastic carbonate unit Valanginian in age and acknowledged as Seroula Formation (Khessibi, 1967) and the Hauterivian deposits made by mixed shelf deposits ended with carbonate platform.

The Barremian sequences began with mixed tempestites, followed by a thick carbonate shoals with reworked corals, topped by storm deposits within offshore muds, themselves followed by anoxic marlmudstone parasequences (Souquet et al., 1997). In northern Tunisia, the Valanginian-Aptian open marine shaly series are attributed to the M'Cherga Formation (Burollet, 1956; Ben Ferjani et al., 1990). The Aptian-Early Albian sequences are relatively made of deep-water type showing gray to black marls. The Aptian series in this region present frequent traces of lamination which is the witnesses of the local thickness reduction of these series (Turki, 1980). In the northern portion of Jebel Boulahouadjeb, the Aptian marls are covered by Triassic salt suggesting an active salt tectonic period. In addition, the Aptian sequences show abundant slumps and calcareous nodules clearly linked to a contemporaneous sub-marine slope. Furthermore, salt tectonics which is active during this period, and responsible for the emplacement of large submarine salt sheet and salt rise can also enhance this slope (Masrouhi et al., 2013).

The Correlation of the Lower Cretaceous series (Fig. 3), drawn from Jebel Sidi-Salem in the Southeast to Jebel Boulahouadjeb in the Northwest, shows a significant thicknesses changes ranging from tens to hundreds of meters but with preservation of the lithology which remains in all sections a pelagic to hemi-pelagic facies.

A significant thickening is perceived at Jebel Oust (2600 m-thick Barremian-Aptian series) and Jebel Boulahouadjeb (2000 m-thick Hauterivian-Barremian series), however these series are relatively reduced with $310 \mathrm{~m}$ at Jebel Sidi-Salem and 450 at Oued Tazega (Fig. 3). Jebel Boulahouadjeb was, likely, a significant depocenter with a very high rate of sedimentation, created in response to active and extensional Cretaceous tectonics (Souquet et al., 1997; Masrouhi et al., 2013). Furthermore, the series outcropping from either side of the Zaghouan fault reflects a reduction in thickness toward the southeast compared to the Jebel Oust's type-section. Apparently, no significant flexure has worked at the base of the current Zaghouan fault during the Barremian, but we are led to imagine a synsedimentary flexure or rather a set of flexures further west separating subsiding areas of the Tunisian trough (Jebel Oust) from other edge series with reduced thickness (Turki, 1988, El khazri et al., 2013).

The correlation, of the Lower Cretaceous sequences, likely reflects an irregular sea floor probably created by tectonic extension (Masrouhi et al., 2013). The Lower Cretaceous extension is also testified 
173 by numerous synsedimentary features (nodule reworking, slumps, olistholites, active salt tectonics...).

174 The Lower Cretaceous deposits in central and northern Tunisia can be divided into four second order 175 cycles. The first two cycles extending from Late Tithonian to Hauterivian are included within the rifting phase where basement block-faulting predominates (tilted blocks). Third and fourth cycles extend from Barremian to Albian are likely produced by the intra-basin growth faulting (Souquet et al., 1997).

Upper Cretaceous deposits show, in all northern Tunisia, homogeneous facies mainly composed of marls and fine-grained limestones (Fig. 4). The Albian-Cenomanian series are defined as Fahdene Formation wholly formed by limestone-marl alternations and topped by the thinly laminated organicrich limestones of Bahloul Formation, dated as Uppermost Cenomanian-Turonian (Soua and Tribovillard, 2007). Over the Fahdene Formation, rest a thick series of gray marl and shale interbedded with fine-grained limestones. These series are attributed to the Turonian-Early Campanian Aleg Formation (Burollet, 1956). The Campanian-Maastrichtian series (Abiod Formation) are essentially made by chalky limestones.

The correlation of the upper Cretaceous series (Fig. 4) shows no significant variation in facies (all sequences are of pelagic to hemi-pelagic facies; Floridia, 1963; Ben Yagoub, 1978, Turki, 1988; Soua and Tribovillard, 2007). However, clearly considerable thickness variation is perceived along the northern Tunisia. From Upper Albian to Coniacian-Santonian, thicknesses significantly vary from tens to hundreds of meters for the equivalent formations from section to other. This correlation clearly reflects a persisted tilted blocks geometry, revealed for the Early Cretaceous, and likely shaped by major synsedimentary normal fault systems.

\subsection{Slumping and faulting analysis}

\subsubsection{Dataset and methodology:}

To study the tectono-sedimentary evolution and the related submarine paleoslope of the southern Tethyan margin in the northern Tunisia, field data collection and detailed geologic mapping have been carried out. Stereonet 9 (Allmendinger et al., 2013; Cardozo and Allmendinger, 2013), failles software (Carey, 1979; Carey and Brunier, 1974) and canvas drawing software have been used in data plotting and analysis. Particularly, two elements are surveyed: the faults kinematics related to the the tectonic regime and slump folds analysis which supports the reconstruction of the paleoslope orientation (Alsop and Holdsworth, 2007; Van Loon, 2009; Lacelle, et al., 2015).

The brittle deformation is frequently quantified using fault kinematic analysis methods. These methods are based on measurements of centimetric to metric scales faults planes and striae. Fault kinematic analysis commonly determines the reduced stress tensor and the directions and plunges of principal 
stresses $\left(\sigma_{1}, \sigma_{2}, \sigma_{3}\right)$. This inferred stress tensors reflect a local state of stress. To deduce the original stress tensors, we rotated all fault data to restore the bedding plane to its horizontal orientation.

Several techniques have been developed for the deduction of the paleoslope direction from the study of slump fold axis. Jones (1940) was the first who applied this idea quantitatively. Recently, other studies have focused on the study of slump folds and have described other methods estimating the paleoslope direction from these structures (e.g. Hansen, 1965, 1967; Woodcock, 1979; Bradley and Hanson, 1998; Alsop et al., 2001; Strachan and Alsop, 2006; Strachan, 2008; Debacker and Meester, 2009; Alsop and Marco, 2011, 2012a, b, 2013, 2014; Debacker, 2012; Yong et al., 2013; Sharman, 2014). Two methods are used in this study (Fig. 2): the MAM (Mean Axis Method) and the APM (the AxialPlanar Method).

The MAM, proposed initially by Jones (1939), assumes that slumps fold axes are statistically parallel to the paleoslope and perpendicular to the translation direction of the sheet. To apply this method, we need to rotate either the original data, or at least the derived paleoslope directions, in order to remove later tectonic effects. This method brings about two diametrically opposed possibilities for the direction of the paleoslope (Fig. 2). The latter is usually chosen basically on regional paleogeographic constraints (Jones, 1939), and/or the vergence of slump folds (Woodcock, 1976b). The MAM has the advantage of being statistically robust because it is based on average properties of slump measurements. The major disadvantage of the MAM is that it does not allow for fold axes that are oriented in parallel or oblique way to the downslope direction (Woodcock, 1979). The APM, treating the Fold axial surfaces (approximated as axial planes), yields important kinematic information in a similar way as fold axes (Woodcock, 1976a, 1979b; Farrell and Eaton, 1987, Sharman, 2014). Through APM (Fig. 2), poles to axial planes tend to align in a great circle around the mean fold axis, and thus the plane through the best-fit girdle to these poles gives a bi-directional estimate of the slumps transport direction (Woodcock, 1976b, Sharman, 2014). Furthermore, the imbrication of the mean axial plane with respect to the global slumps orientation can be used to evaluate the paleoslope dip direction (Woodcock, 1976b).

\subsubsection{Results of synsedimentary faults analysis}

The current study, of faults and slump folds, is based on new structural data collected from seven localities which are respectively from the Southeast to the Northwest the Jebel Sidi Salem - Messella, Jebel Oust, Jebel Rihane, Jebel Kechtilou, Oued Tazegga, Jebel Bechtab and Jebel Boulahouadjeb. The Sidi Salem-Messella is a NE-trending structure located along the Zaghouan-Ressas thrust system. The Present survey together with previous works (Turki, 1988; Morgan et al., 1998) affirms that this present-day thrust system (Fig. 5a) is the result of the inversion of major inherited normal faults. Field data shows a layer's geometry of growth strata likely related to an early normal faulting acting during 
Aptian-Albian times and as well probably active before. Likewise, Aptian-Albian sequences display abundant conglomeratic horizons and slumping, in addition to significant thickness changes. Besides, the Sidi Salem-Messella structure shows abundant centimetric, metric to decametric-scale sealed normal faults (Fig. 5). The collected faults data are rotated, using fault diagram, to their original orientation to restore initial tectonic extension. The back-tilting, of faulting, highlights a normal fault type predating the Cenozoic folding (Fig. 5). This kinematics analysis of normal faulting (Fig. 5b) typifies a minimum stress axis $\sigma_{3}$-trending $\sim \mathrm{N} 25^{\circ} \mathrm{E}$ during the Aptian time. During Albian times, the tectonic regime is characterized by $\sim \mathrm{N} 201^{\circ} \mathrm{E}$-trending minimum stress $\left(\sigma_{3}\right)$ axis (Fig. $5 \mathrm{C}$ ). This setting was likely responsible for half-graben geometry structure of the Jebel Sidi Salem-Messella area.

$15 \mathrm{~km}$ northward, the Jebel Oust is a $15 \mathrm{~km}$-large $\mathrm{N} 40^{\circ} \mathrm{E}$-trending anticline structure with Jurassic to Maastrichtian outcrops (Fig. 6a). In this locality, considered as the type-section of Lower Cretaceous (Ben Ferjani et al., 1990; Souquet et al., 1997), 2600 m-thick siliciclastic and marly sequences have been deposited. The Barremian-Aptian series show numerous small-scale synsedimentary normal faults preserved within siliciclastic sediments. The Barremian sediments are affected by normal faulting (Fig. $6 \mathrm{~b}$ ) locally characterized by $\sim \mathrm{N} 272^{\circ} \mathrm{E}$-trending minimum stress axis $\left(\sigma_{3}\right)$. During Aptian times, the Jebel Oust area seems also to be controlled by the same fault population acting as normal faults with an extensional trending $\sim \mathrm{N} 251^{\circ} \mathrm{E}$ (Fig. $6 \mathrm{c}, \mathrm{d}$ ).

The Jebel Rihane corresponds to a WNW-to NW-trending large syncline structure (Fig. 7a) situated eastern of Jebel Oust structure and it is mainly made of Upper Cretaceous deposits (Arfaoui, 2007). This structure seems to be controlled essentially by E-to NE-trending faults. Locally, field results highlight that most faults have steep planes (Fig. 7b, c) suggesting that they occurred in a local transtensive stress regime which controlled the sedimentation in this small area since the Albian times. The back-tilted Albian fault diagram shows a transtensive tectonic regime with $\sim \mathrm{N} 354^{\circ} \mathrm{E}$ trending tectonic extension.

The Jebel Kechtilou is a NE-trending faulted anticline (Fig. 8a). This is one of numerous structures disturbed during Cretaceous rifting by the ascendant movement of Triassic evaporites. Active extensional tectonics recorded all along the Jebel Kechtilou within Aptian-Albian deposits (Haggui, 2012). The Albian series show number of a mesoscale synsedimentary normal faults. The back-tilted fault diagram shows $\sim \mathrm{N} 359^{\circ}$ E trending tectonic extension during Albian time (Fig. $8 \mathrm{~b}$ ). In addition, numerous metric Aptian 'olistostromes' are interpreted to be derived from submarine gravity sliding in Albian series (Fig. 8c). Frequent reworked blocks, slumps, and nodules joined the Aptian-Albian extensional tectonic regime. Furthermore, these tectonic events induced variation in thickness (Fig. $8 d)$ and facies of Cretaceous series prior to the tectonic inversion. 
272 The Jebel Bechtab located in the Lansarine belt (Fig. 9a) shows a NNE-trending faulted structure, 273 intersected by Triassic evaporitic bodies. This structure is made of Hauterivian-Barremian to OligoMiocene sequences (Masrouhi et al., 2013). Mains faults observed in this zone are NW-dipping normal faults. Detailed observation of fault planes argues for an early normal displacement before Cenozoic compression which reverse them as strike-slips. Albian fault population of Glib El Abiod locality (Fig. 9b) indicates a normal faulting resulting from extensional tectonic regime locally characterized by $\sim \mathrm{N} 344^{\circ} \mathrm{E}$-trending minimum stress axis $\left(\sigma_{3}\right)$. During Cenomanian times, the Bechtab area is also controlled by comparable fault population acting as normal faulting with $\sim \mathrm{NOO2}^{\circ} \mathrm{E}$-trending extensional tectonic (Fig. 9c).

\subsubsection{Slumps analysis results}

The Lower Cretaceous sequences are marl-dominated and deposited in an unstable basin floor affected by extensional tectonics. In such conditions, the instability of locally oversteepened slopes together with seismotectonic activity can trigger slumps within shallow marls and mudrocks before they are lithified. Numerous slump folds have been identified. After rotation of bedding data to restore the bedding planes in its horizontal orientation, these deformations are observed only within a restricted stack of marly strata argue for synsedimentary slump folding and not micro and/or mesofolding resulting from permanent compressions.

21 slump folds were studied in the Jebel Oust locality, which are recorded throughout Berriasian, Valanginian and Barremian sequences. Slump folds of Jebel Oust are upright to recumbent folds (Fig.10). Both MAM and APM methods applied for 10 samples of slumps observed within the Berriasian series gives $\sim$ N331 trending paleoslope (Fig.10a). For the Valanginian slump folds, the use of the APM and MAM reveals $\sim$ SSW-mean downslope transport direction. The back-tilting of 6 slump folds from the Valanginian siliciclastic carbonates deposits using MAM and APM methods give very close values of paleoslope trend, respectively N202 and N201 (Fig. 10b). The Barremian sequences are topped by a carbonate level bar which is formed by Black nodular limestones followed by thick fine clayey limestones and green marls alternations. Within this carbonate level bar 5 slump folds are measured and unfolded-back to their horizontal position. Results of the determination techniques display a general NW-dipping paleoslope. The back-tilted axis gives N310 value and the back-tilted poles of axial planes gives $\sim$ N318 value (Fig. 10c).

30147 slump folds within the Aptian-Albian series are analyzed in this work. Slump folds are observed 302 within green-black marls series interbedded by fine marly limestone in the base and within the middle 303 marls interbedded with black clayey limestone. All of them are topped by clayey platy limestone with 304 dark gray marls of Upper Albian. Abundant slump folds are accompanied by frequent resedimented 305 blocks and nodules. Albian epoch is considered by authors (e.g. Saadi et al., 1994; Masrouhi et al., 
2014a, Jaillard et al., 2017) as a maximum regional extension period of the Cretaceous rifting in northern Tunisia. Slump folds' geometries, observed in the studied sections, suggest a wide fold types ranging from open hinge folding to steeply inclined (Figs. 11, 12). In Jebel Sidi Salem-Messella, 25 slump folds are analyzed. The Analysis of unfolded slump axis gives N030-trending paleoslope, whereas the unfold poles of axial planes (APM method) give comparable value of $\sim$ N025-trending paleoslope (Fig. 11a). These results are in accordance with a general Aptian-Albian NNE-trending paleoslope. Westward, slump folds belonging to the Jebel Rihane structure show a general SSEtrending mean slump transport direction. The computed values of paleoslope trend derived from MAM and APM methods are: $\sim$ N150 and $\sim$ N160 respectively (Fig. 11b). Northward, in Jebel Kechtilou numerous slump folds are measured within the Aptian-Albian marls and limestones alternations. Using the two methods above, a general NNE-trending paleoslope of the basin floor seems to be dominant during Aptian-Albian times. The back-tilted axis method gives a paleoslope trend of $\sim$ N017, and, the back-tilted poles of axial planes gives N030 (Fig. 11C). The structures of Jebel Bechtab, Oued Tazegga and Jebel Boulahouadjeb lie on the northern tip of the study area. The Cretaceous series of these structures are characterized by larger, sometimes decametric, slump folds. The pre-tilted slump axis and poles to axial surfaces give a general $\sim$ S-trending paleoslope $(\sim S, \sim S S E$, and $\sim$ SSW respectively in the Jebel Bechtab, Oued Tazegga and Jebel Boulahouadjeb). The following results are obtained: in the Jebel Bechtab, the back-tilted axis gives N175-trending paleoslope, and, the back-tilted poles of axial planes give N173-trending slope (Fig. 12a). In the Oued Tazegga, the results of two MAM and APM methods are respectively N151 and N156-trending paleoslope (Fig. 12b). In the Jebel Boulahouadjeb structure, the analysis of unfolded slump axis gives N202-trending paleoslope, whereas the unfold poles of axial planes (APM method) give a N205-trending paleoslope (Fig. 12c).

The Cenomanian series show an abundant instability features classified also to be soft-sediment deformation related to the Cretaceous extension in north-eastern Tunisia. In this area, 32 slump folds were analyzed in the Jebel Sidi Salem-Jebel Messella, Jebel Kechtilou and Jebel Bechtab structures. The analysis of slump folds' data shows a general $\mathrm{N}$ - downslope transport direction. The unfolded slump axis (MAM Method) gives N004-trending paleoslope, and, the unfold poles of axial planes (APM method) show a similar paleoslope direction with N008-trending paleoslope (Fig. 13a). Westward, In Jebel Kechtilou, a general S-dipping paleoslope is highlighted. The Analysis of unfolded slump axis (MAM method) gives N196-trending paleoslope, and the unfold poles of axial planes (APM method) gives N186-trending paleoslope (Fig. 13b). Northward, in the northern flank of Jebel Bechtab (Glib El Abiod locality), Cenomanian series exhibit well identified slump features. The back-tilted slump axis and poles of axial planes give very close results highlighting a general $\sim \mathrm{S}$-dipping paleoslope. The MAM and APM methods give respectively $\sim$ N172 and $\sim$ N167-trending paleoslope (Fig. 13c). 
North Africa is part of the Southern Tethyan rifted continental margin during Mesozoic times. The rift stage, started during Permian (?)-Triassic, is followed during Jurassic and Cretaceous times by passive margin basin's style (Tlig, 2015). During the syn-rift and post-rift stages, which is associated with the opening of the Tethyan and Central Atlantic oceans, north Tunisia area corresponds to basin that was filled with $\sim 5$-to 6 -km-thick sedimentary succession. Although the geodynamic evolution of the southern Tethyan margin in Tunisia have been considered by several authors, the gravity-driven deformational structures are still insufficiently studied.

The Lower Cretaceous series, showing a significant thicknesses variation, were likely deposited above an irregular sea floor. Synsedimentary features (slumps, sealed normal faults, conglomerates, thickness variation...) testify for Mesozoic extensional tectonic regime and display character of related growth strata. The basin is itself part of the Southern Tethyan rifted continental margin (Basilone et al., 2014; Basilone and Sulli, 2016). Using slump folds transport determination techniques (MAM and APM), the basin paleoslope exhibit a variable trend through Early Cretaceous times (Table 1); this paleoslope is $\sim N W$-dipping during Berriasian, $\sim$ SSW-trending during Valanginian and $\sim N W$-dipping during the Barremian. During Aptian-Albian period, perceived to have the most extreme extensional related-structures time of the south Tethyan edge in North Tunisia (Masrouhi et al., 2013; Dhahri and Boukadi, 2017, Jaillard et al., 2017), a significant paleogeographic differentiation is identified in Tunisia. The direction of paleoslope inferred from slump axis and from poles of Axial planes confirms this paleogeography by giving $\sim \mathrm{N}$ - to $\sim$ NNE or $\sim S$ - to $\sim S S W$-dipping paleoslope (Table 1). Fault kinematics deduced from the study of back-tilting striated fault planes display evidence for $\sim N-S$ to $\sim N E-S W$ direction of the tectonic extension. Based on this study and numerous previous paleogeographic data (e.g. Souquet et al., 1997; Ben Fadhel et al., 2011; Soua, 2016), the Lower Cretaceous deposits of the Tunisian Atlas can be divided into four second order cycles. The first two cycles extending from Late Tithonian to Hauterivian are included within the rifting phase where basement block-faulting predominates (tilted blocks). Third and fourth cycles extend from the Barremian to Albian are likely produced by the intra-basin growth faulting (Fig. 14). Since the Cenomanian, the facies heterogeneity decreases. The homogeneity of the Upper Cretaceous facies likely reflects a basin post-rifting subsidence history. The back-tilted fault diagrams show $\sim \mathrm{N}-\mathrm{S}$ to $\sim \mathrm{NE}-\mathrm{SW}$ extension during Cenomanian time which indicates that the Albian E- and NW-trending faults remain active during Cenomanian. This faults system is likely an inherited Albian faulting that controls a general northward basin's submarine slope (Fig. 14). The back-tilted slump axis and poles of axial planes (MAM and APM respectively) give

372 very close results with a $\sim \mathrm{S}$ or $\sim \mathrm{N}$-dipping paleoslope which confirms the $\sim \mathrm{N}$ to NE-trending extension 373 during Cenomanian time. During Upper Cretaceous, an extensional period of post-rift stage is 
374 highlighted, showing pelagic deposits controlled probably by the isostatic response of different major 375 fault systems and/or depocenters (Gharbi et al., 2013). Coniacian-Santonian deposits seem to seal all the aforementioned differentiation and described as post-rift marl-rich sequences followed by limestone and marl sequences approximately homogeneous in the entire basin. During the Upper Cretaceous, this region was a transtensive paleomargin, at least until earliest the Campanian (Masrouhi et al., 2008, Gharbi et al., 2013).

\section{5. conclusion}

381

The analysis of slump folds and the synsedimentary normal faults data together with sequences correlation permits us to precise the variation of the paleoslope trend during Cretaceous times in northern Tunisia. In detail, this paleoslope is NW-dipping during Berriasian, SSW-trending during Valanginian and $\sim \mathrm{NW}$-dipping during the Barremian and $\sim \mathrm{N}$ - to $\sim$ NNE or $\sim \mathrm{S}$ - to $\sim \mathrm{SSW}$-dipping during Aptian-Albian period. In this area, passive margin gravity deformations occurred during Lower Cretaceous and continued at least to the Cenomanian. During Cenomanian, the inherited fault systems likely active since Albian controls a general northward basin's submarine slope. with a $\sim \mathrm{S}$ or $\sim \mathrm{N}$-dipping paleoslope. Abundant soft-sediment deformations and slumping are shaped onto a regional northward to southward facing submarine slope that reflect the intra-basin growth faulting associated to Triassic salt rise up during Cretaceous times. The extensional regime that qualified this is responsible for the development of major synsedimentary normal fault systems producing tilted blocks basin geometry characterizing a general $\sim$ North-South tectonic extension, related to the Southern Tethyan rifted continental margin.

\section{Acknowledgements:}

Authors are indebted to Pr. N.H. Woodcock, Pr. I. G. Alsop and Dr. L. J. Strachan for great helpful discussions about the methodology, transport determination techniques and interpretation of slump folds. The stereonet 9 software, written by Allmendinger, R. was used. The authors are grateful to the Editor-in-Chief Pr. Gregory Price as well as Dr. Ferid Dhahri and Pr. Ian Alsop for careful reading and valuable suggestions and comments that improved the manuscript. 


\section{References}

Allmendinger, R. W., Cardozo, N. C., Fisher, D., 2013. Structural Geology Algorithms: Vectors \& Tensors. Cambridge, England, Cambridge University Press, 289.

Alsop, G. I., Marco, S., 2014. Fold and fabric relationships in temporally and spatially evolving slump systems: A multi-cell flow model. Journal of Structural Geology, 63, 27-49.

Alsop, G. I., Marco, S., 2013. Seismogenic slump folds formed by gravity-driven tectonics down a negligible subaqueous slope. Tectonophysics, 605, 48-69.

Alsop, G.I., Marco, S., 2012a. A large-scale radial pattern of seismogenic slumping towards the Dead sea basin. Journal of the Geological Society, 169, 1, 99-110.

Alsop, G. I., Marco, S., 2012b. Tsunami and seiche-triggered deformation within offshore sediments. Sedimentary Geology, 261-262, 90-107.

Alsop, G. I., Marco; S. 2011. Soft-sediment deformation within seismogenic slumps of the Dead Sea Basin. Journal of Structural Geology, 33, 433-457.

Alsop, G. I., Holdsworth, R. E., 2007. Flow perturbation folding in shear zones. In: Ries, A.C., Butler, R.W.H., Graham, R.D. (Eds.), Deformation of the Continental Crust: the Legacy of Mike Coward. Geological Society, London, Special Publications, 272, pp. 77-83.

Alsop, G. I., Bryson, R., Hutton, D. H. W., 2001. Tectonic and kinematic evolution within mid-crustal orogenic root zones: a case study from the Caledonides of northwestern Ireland. Geological magazine, $138(2), 193-211$.

Arfaoui, M, S., 2007. Etude géologique des structures associées au fossé de Bou Arada. Master's thesis, University of Tunis II, Tunis. p 159.

Barrier, E., Vrielynck, B., 2008. Palaeotectonic maps of the Middle East. Tectono-sedimentarypalinspastic maps from Late Norian to Piacenzian. Commission for the Geological Map of the World (CGMW).

Basilone, L., Sulli, A., 2016. A facies distribution model controlled by a tectonically inherited sea bottom topography in the carbonate rimmed shelf of the Upper Tithonian-Valanginian Southern Tethyan continental margin (NW Sicily, Italy). Sedimentary Geology, 342, 91-105.

Basilone, L., Lena, G., Gasparo-Morticelli, M., 2014. Synsedimentary-tectonic, soft-sediment deformation and volcanism in the rifted Tethyan margin from the Upper Triassic-Middle Jurassic deepwater carbonates in Central Sicily. Sedimentary Geology, 308, 63-79.

Ben Fadhel, M., Layeb, M., Hedfi, A., Ben youssef, M., 2011. Albian oceanic anoxic events in northern Tunisia: Biostratigraphic and geochemical insights. Cretaceous Research, 32, 685-699.

Ben Ferjani, A., Burollet, P. F., Mejri, F., 1990. Petroleum Geology of Tunisia. ETAP publication, 194p. 
Ben Yagoub, J., 1978. Etude géologique de la région de Bou Arada (Atlas tunisien). PhD thesis (Thèse 3ème cycle), Pierre-et-Marie-Curie University (Paris VI), 91 pp.

Bradley, D., Hanson, L., 1998. Paleoslope Analysis of Slump Folds in the Devonian Flysch of Maine. The Journal of Geology, 160, 305-318.

Burollet, P.F., 1956. Contribution à l'étude stratigraphique de la Tunisie centrale. Ann. Mines. Géol. Tunisie 18, $352 \mathrm{p}$, Tunis.

Cardozo, N., Allmendinger, R. W., 2013, Spherical projections with OSX Stereonet. Computers \& Geosciences, 51, 193-205.

Carey, E., 1979. Recherche des directions principales de contraintes associées au jeu d'une population de failles. Rev. Geol. Dyn. Geogr. Phys. 21, 57-66.

Castany, G., Guigon, M., Jauzein, A., 1957. Geologic Map of Tunisia 1:50.000, sheet n²8, Bir M'cherga. National Office of Mines, National Geological Survey, Tunisia.

Carey, E., Brunier, B., 1974. Analyse théorique et numérique d'un modèle mécanique élémentaire appliqué à l'étude d'une population de failles. C. R. Acad. Sci. Ser. D., 279, 891-894.

Chihaoui, A., Jaillard, E., Latil, J. L., Zghal, I., Susperregui, A. S., Touir, J., Ouali, J., 2010. Stratigraphy of the Hameima and lower Fahdene Formations in the Tadjerouine area (Northern Tunisia). Journal of African Earth Sciences, 58, 387-399.

Chihi, L., 1992. Sismotectonic study in central and southern Tunisia. Tectonophysics, 209, 175-178.

Debacker, T. N., 2012. Folds and cleavage/fold relationships in the Brabant Massif, southeastern AngloBrabant Deformation Belt. Geologica Belgica, 15, 1-2, 81-95.

Debacker, T. N., De Meester. E., 2009. A regional, S-dipping late Early to Middle Ordovician palaeoslope in the Brabant Massif, as indicated by slump folds (Anglo-Brabant Deformation Belt, Belgium). Geologica Belgica, 12, 3-4, 145-159.

Floridia S., 1963 : Contribution à l'étude géologique de Jebal Rihane. Dipl. Ing. Géol. Ecole Nat. Sup. du pétrole, Paris.

Frizon de Lamotte, D., Bezar, B. S., Bracène, R., Mercier, E., 2002. The two main steps of the atlas building and geodynamics of the Western Mediterranean. Tectonics, 19 (4), 740-761.

Dhahri, F., Boukadi, N., 2010. The evolution of pre-existing structures during the tectonic inversion process of the Atlas chain of Tunisia. Journal of African Earth Sciences, 56, 139-149. Dhahri, F., Boukadi, N., 2017. Triassic salt sheets of Mezzouna, Central Tunisia: New comments on Late Cretaceous halokinesis and geodynamic evolution of the northern African margin. Journal of African Earth Sciences, 129, 318-329. 
El khazri, A., Abdallah, H., Razgallah, S., Moullade, M., Kuhnt, W., 2013. Carbon-isotope and microfaunal stratigraphy bounding the Lower Aptian Oceanic Anoxic Event 1a in northeastern Tunisia. Cretaceous Research, 39, 133-148.

El Ouardi, H., 1996. Halocinèse et rôle des décrochements dans l'évolution géodynamique de la partie médiane de la zone des dômes. PhD thesis, University of Tunis II, Tunis.

Haggui, M., 2012. Mécanismes de l'halocinèse de la structure salifère du Jebel Kechtilou (monts de Testour, Tunisie du nord) : comparaison et modèle. Master's Thesis, University of Sfax, p 73.

Heifetza, E., Agnonb, A., Marco, M., 2005. Soft sediment deformation by Kelvin Helmholtz Instability: A case from Dead Sea earthquakes. Earth and Planetary Science Letters, 236, 497-504.

Eva, S. J., Maltman, A. J., 1994. Slump-fold and Paleoslope orientations in Upper Silurian rocks, North Wales. Geological magazine, 131, 5, 685-691.

Gharbi, M., Masrouhi, A., Bellier, O., Naji, Ch., Ben Youssef, M., In prepa. From Jurassic rifting to Miocene shortening: An example of polyphase deformation along the Zaghouan-Ressas thrust belt, Northern Tunisia.

Gharbi, M., Masrouhi, A., Espurt, N., Bellier, O., Amari, E., Ben Youssef, M., Ghanmi, M., 2013. New tectono-sedimentary evidences for Aptian to Santonian extension of the Cretaceous rifting in the Northern Chotts range (Southern Tunisia). Journal of African Earth Sciences, 79, 58-73.

Gharbi, M., Bellier, O., Masrouhi, A., Espurt, N., 2014. Recent spatial and temporal changes in the stress regime along the southern Tunisian Atlas front and the Gulf of Gabes: new insights from fault kinematics analysis and seismic profiles. Tectonophysics, 626, 120-136.

Gharbi, M., Espurt, N., Masrouhi, A., Bellier, O., Amari, E. A., 2015. Style of Atlassic tectonic deformation and geodynamic evolution of the southern Tethyan margin, Tunisia. Mar Pet Geol., 66, 801-816.

Guiraud, R., 1998. Mesozoic rifting and basin inversion along the northern African Tethyan margin: an overview. In: MacGregor, D.S., Moody, R.T.J., Clark-Lowes, D.D. (Eds.), Petroleum Geology of North Africa. Geological Society, London, Special Publication, 133, 217-229.

Guiraud, R., Bosworth, W., 1997. Senonian basin inversion and rejuvenation of rifting in Africa and Arabia: synthesis and implications to plate-scale tectonics. Tectonophysics $282,39-82$.

Guiraud, R., Bosworth, W., Thierry, J., Delplanque, A., 2005. Phanerozoic geological evolution of Northern and Central Africa: an overview. J. Afr. Earth Sci. 43, 83-143.

Jaillard, E., Dumont, T., Ouali, J., Bouillin, J. P., Chihaoui, A., Latil, J. L., Arnaud, H., Arnaud-Vanneau, A., Zghal, I., 2013. The Albian tectonic "crisis" in Central Tunisia: Nature and chronology of the deformations. Journal of African Earth Sciences, 85, 75-86. 
Jaillard, E., Bouillin, J. P., Ouali, J., Dumont, T., Latil, J. L., Chihaoui, A., 2013. Albian salt-tectonics in Central Tunisia: Evidences for an Atlantic-type passive margin. Journal of African Earth Sciences, 135, 220-234.

Jones, O.T., 1939. The geology of the Colwyn Bay district: a study of submarine slumping during the Salopian period. Quarterly Journal of the Geol. Soc. London, 380, 335-382.

Jones, O. T., 1940, On the sliding or slumping of submarine sediments in Denbighshire, North Wales, during the Ludlow Period: Geol. Soc. London Quart. Jour., 93, 241-283.

Khessibi, M., 1967. Etude stratigraphique et structurale des formations mésozoïques de DjedeidaBeauvoir (Tunisie), Geol. High study diploma. University of Tunis, 80p.

Lacelle, D., Brooker, A., Fraser, R. H., Kokelj, S. V., 2015. Distribution and growth of thaw slumps in the Richardson Mountains-Peel Plateau region, northwestern Canada. Geomorphology, 235, 40-51.

Masrouhi, A., Bellier, O., Koyi, H., Vila, J. M., Ghanmi, M., 2013. The evolution of the Lansarine-Baouala salt canopy in the North African Cretaceous passive margin in Tunisia. Geological magazine, 150, 5, 835-861.

Masrouhi, A., Ghanmi, M., Ben Slama, M. M., Ben Youssef, M., Vila, J. M., Zargouni, F., 2008. New tectono-sedimentary evidence constraining the timing of the positive tectonic inversion and the Eocene Atlasic phase in northern Tunisia: Implication for the North African paleo-margin evolution. C. R. Geoscience, 340, 771-778.

Masrouhi, A., Bellier, O., Ben Youssef, M., Koyi, H., 2014. Submarine allochthonous salt sheets: gravitydriven deformation of North African Cretaceous passive margin in Tunisia - Bled Dogra case study and nearby salt structures. J. Afr. Earth Sci. 97,125-142.

Masrouhi, A., Koyi, H. A., 2014. Submarine 'salt glacier' of Northern Tunisia, a case of Triassic salt mobility in North African Cretaceous passive margin. Geological Society, London, Special Publications, $363,579-593$.

Mattoussi Kort, H., Gasquet, D., Ikenne, M., Laridhi Ouazaa, N., 2009. Cretaceous crustal thinning in North Africa: Implications for magmatic and thermal events in the Eastern Tunisian margin and the Pelagic Sea. Journal of African Earth Sciences, 55, 5, 257-264.

Morgan, M. A., Grocott, J., Moody, R. T. J., 1998. The structural evolution of the Zaghouan-Ressas Structural Belt, northern Tunisia. Geological Society, London, Special Publication, 132,405-422.

Peel, F. J., 2014. The engines of gravity-driven movement on passive margins: Quantifying the relative contribution of spreading vs. gravity sliding mechanisms. Tectonophysics, 633, 126-142.

Rami, A., 1998. Stratigraphie, micropaléontologie et environnements de dépôt du Crétacé supérieur de la Tunisie Centro-septentrionale. PhD thesis, University of Tunis II, Tunis, 277 p., 22 pl. 
533 Saadi, J., Ben Youssef, M., Souquet, P., Peybernes, B., Andreu, B., 1994. Stratigraphie séquentielle du

534 Crétacé inférieur de la région d’Enfidha (NE de la Tunisie). C. R. Acad. Sci. Paris 323 (II), 119-125.

535

536 Soua, M. 2016. Cretaceous oceanic anoxic events (OAEs) recorded in the northern margin of Africa as possible oil and gas shale potential in Tunisia: An overview. International Geology Review, 58, 3, 277-320.

Soua, M., Tribovillard, N., 2007. Modèle de sédimentation au passage Cénomanien/Turonien pour la formation Bahloul en Tunisie. Cretaceous Research, 339, 692-701.

Souquet, P., Peybernes, B., Saadi, J., Ben Youssef, M., Ghanmi, M., Zarbout, M., Chikhaoui, M., Kamoun, F., 1997. Séquences et cycles d'ordre 2en régime extensif et transtensif: exemple du Crétacé inférieur de l'Atlas tunisien. Bull. Soc. Géol. France, 168, 373-86.

Soussi, M., Niedźwiedzki, G., Tałanda, M., Dróżdż, D., Sulej, T., Boukhalfa, K., Mermer, J., Blazejowski, B., 2017. Middle Triassic (Anisian-Ladinian) Tejra red beds and Late Triassic (Carnian) carbonate sedimentary records of southern Tunisia, Saharan Platform: Biostratigraphy, sedimentology and implication on regional stratigraphic correlations. Marine and Petroleum Geology, 79, 222-256.

Strachan, L. J., 2008. Flow transformations in slumps: a case study from the Waitemata Basin, New Zealand. Sedimentology, 55, 1311-1332.

Strachan, L. J., Alsop, G. I., 2006. Slump folds as estimators of palaeoslope: a case study from the Fisherstreet Slump of County Clare, Ireland. Basin Research, 18, 451-470.

Tlig, S., 2015. The Upper Jurassic and Lower Cretaceous series of southern Tunisia and northwestern Libya revisited. Journal of African Earth Sciences, 110, 100-115.

Tribovillard, N., Algeo, T. J., Baudin, F., Riboulleau, A., 2012. Analysis of marine environmental conditions based on molybdenum-uranium covariation-Applications to Mesozoic palaeoceanography. Chemical Geology, 324-325, 46-58.

Turki, M. M., 1988. Les inversions tectoniques de la Tunisie centro-septentrionale. Bulletin de la Société Géologique de France, 8, no 3, 399-406.

Turki, M. M., 1980. La "faille de Zaghouan" est la résultante des structures superposées (Atlas tunisien centrale). Bulletin de la Société Géologique de France, 7, no 3, 321-325.

Van Loon, A. J., 2009. Soft-sediment deformation structures in siliciclastic sediments: an overview. Geologos, 15 (1), 3-55.

Woodcock, N. H., 1976a. Ludlow Series slumps and turbidites and the form of the Montgomery Trough, Powys, Wales. Proceedings of the Geologists Association, 87, 169-182.

Woodcock, N. H., 1976b. Structural style in slump sheets: Ludlow Series, Powys, Wales. Journal of the Geological Society, London, 132, $399-415$. 
566 Woodcock, N. H., 1979. The use of slump structures as palaeoslope orientation estimators. 567 Sedimentology, 26, 83-99.

568 Yong, L. I., Zhufu, S., Cui, M., Yuping, Y., Shengxin, L., 2013. The seismic induced soft sediment 569 deformation structures in the Middle Jurassic of Western Qaidamu Basin. Acta Geologica Sinica, 87, 4, $570 \quad 979-988$. 


\section{Figures captions}

Figure 1. Location of the studied sections in northeastern Tunisia. The inset on the top left shows the location of Tunisia in North Africa.

Figure 2. fold's patterns in slump sheet. A) Equal area plot of hypothetical fold axis and poles of axial planes distribution to illustrate the mean axis, the separation, and the axial plane methods. The bestfit girdle to axes and poles to axial planes of the slump sheet are horizontals. The paleoslope dips to south (modified from Woodcock, 1979). B) folding generating during layer-parallel shearing (a) and layer-normal shearing (b), see Alsop and Marco, 2011 for more detail, and, associated facing direction (for more detail see Alsop and Marco, 2011, 2012a, b). C) fold facing direction in schematic illustrations summarizing the relationships between folds vergence, axial plane and up-ward or downward facing states (see Alsop and Marco, 2012a).

Figure 3. NE-SW lithostratigraphic correlation of Lower Cretaceous series with the Jebel Oust typesection in northeastern Tunisia.

Figure 4. NE-SW lithostratigraphic correlation of Upper Cretaceous series in northeastern Tunisia.

Figure 5. A) detailed geologic map of Sidi-Salem-Messella structure (Gharbi et al., forthcoming). B) Synsedimentary Aptian normal fault with lower hemisphere stereograms projection of back-tilted striae. C) Synsedimentary Albian normal faults with lower hemisphere stereograms projection of backtilted striae.

Figure 6. A) detail geologic map of Jebel Oust (Castany et al., 1957. B) Synsedimentary Barremian normal faults with Lower hemisphere stereograms projection of back-tilted striae. C) Synsedimentary Aptian normal fault with lower hemisphere stereograms projection of back-tilted striae. D) Detail photo within the synsedimentary fault plane.

Figure 7. A) Geologic map of Jebel Rihane (Arfaoui, 2007). B) Synsedimentary Albian right-lateral fault with lower hemisphere stereograms projection of back-tilted striae. C). Detail photo within the synsedimentary fault plane.

Figure 8. A) Detailed geologic map of Jebel Kechtilou (Haggui, 2012). B) Synsedimentary Albian normal fault with lower hemisphere stereograms projection of back-tilted striae. C) Reworked Aptian limestones in the Albian sequences. D) Inherited normal faulting controlling the sedimentation, inverted later by tertiary compressions.

Figure 9. A) Detailed geologic map of Lansarine belt (Masrouhi et al., 2013). B) Synsedimentary AptianAlbian normal fault with lower hemisphere stereograms projection of back-tilted striae in Oued Tazegga. C) Synsedimentary Cenomanian normal fault with lower hemisphere stereograms projection of back-tilted striae in Glib El Abiod. 
605 Figure 10. Structural data from Slump folds with inferred paleoslope direction in Jebel Oust. A) 606 Berriasian: Field photo with rose diagram of direction of poles to axial planes and lower hemisphere equal area projection of back-tilted slump axis (red box) and poles to axial planes (Blue triangles) with respectively MAM (red arrow) and APM (Blue Arrow) methods. B) Valanginian: same caption as A. C). Barremian: same caption as A.

Figure 11. Structural data from Slump folds with inferred paleoslope direction in Jebel Sidi SalemMessella and Jebel Rihane. A) Aptian-Albian (Jebel Sidi Salem): Field photo with rose diagram of direction of poles to axial planes and lower hemisphere, equal area projection of back-tilted slump axis (red box) and poles to axial planes (Blue triangles) with respectively MAM (red arrow) and APM (Blue Arrow) methods. B) Albian (Jebel Rihane): same caption as A. C). Aptian (Jebel Kechtilou): same caption as $A$.

Figure 12. Structural data from Slump folds with inferred paleoslope direction in Lansarine belt: A) Aptian-Albian (Glib El Abiod): Field photo, with rose diagram of direction of poles to axial planes and lower hemisphere, equal area projection of back-tilted slump axis (red box) and poles to axial planes (Blue triangles) with respectively MAM (red arrow) and APM (Blue Arrow) methods. B) Aptian Albian (Oued Tazegga): same caption as A. C). Aptian (Jebel Boulahouadjeb): same caption as A.

Figure 13. Structural data from slump folds in Upper Cretaceous series with inferred paleoslope direction near Jebel Jebel Sidi Salem-Messella, Jebel Kechtilou and Jebel Bechtab: A) Cenomanian (Jebel Sidi Salem): Field photo with rose diagram of direction of poles to axial planes and lower hemisphere equal area projection of back-tilted slump axis (red box) and poles to axial planes (Blue triangles) with respectively MAM (red arrow) and APM (Blue Arrow) methods. B) Cenomanian (Jebel Kechtilou): same caption as A. C). Cenomanian (Jebel Bechtab): same caption as A.

Table 1: Summary of paleoslope analysis results derived from MAM and APM methods.

Figure 14. Simplified reconstruction of Northern Tunisia Early-to-Late Cretaceous basin. A) Paleogeographic reconstruction map of the western Tethyan domain during the Early Cretaceous (Valanginian, late Hauterivian, early Aptian) and Cenomanian-Turonian transition (modified After, Soua, 2016). Soua's reconstruction was made after Barrier and Vrielynck (2008) and Tribovillard et al. (2012). B) Paleogeographic reconstruction map of the Tunisian domain during the Early Cretaceous, with paleoslope assessment. C) Simplified reconstructed schematic cross-section (not to scale) of Northern Tunisia during Early-Late Cretaceous showing the structural configuration of the area with widespread soft-sediment deformation. 







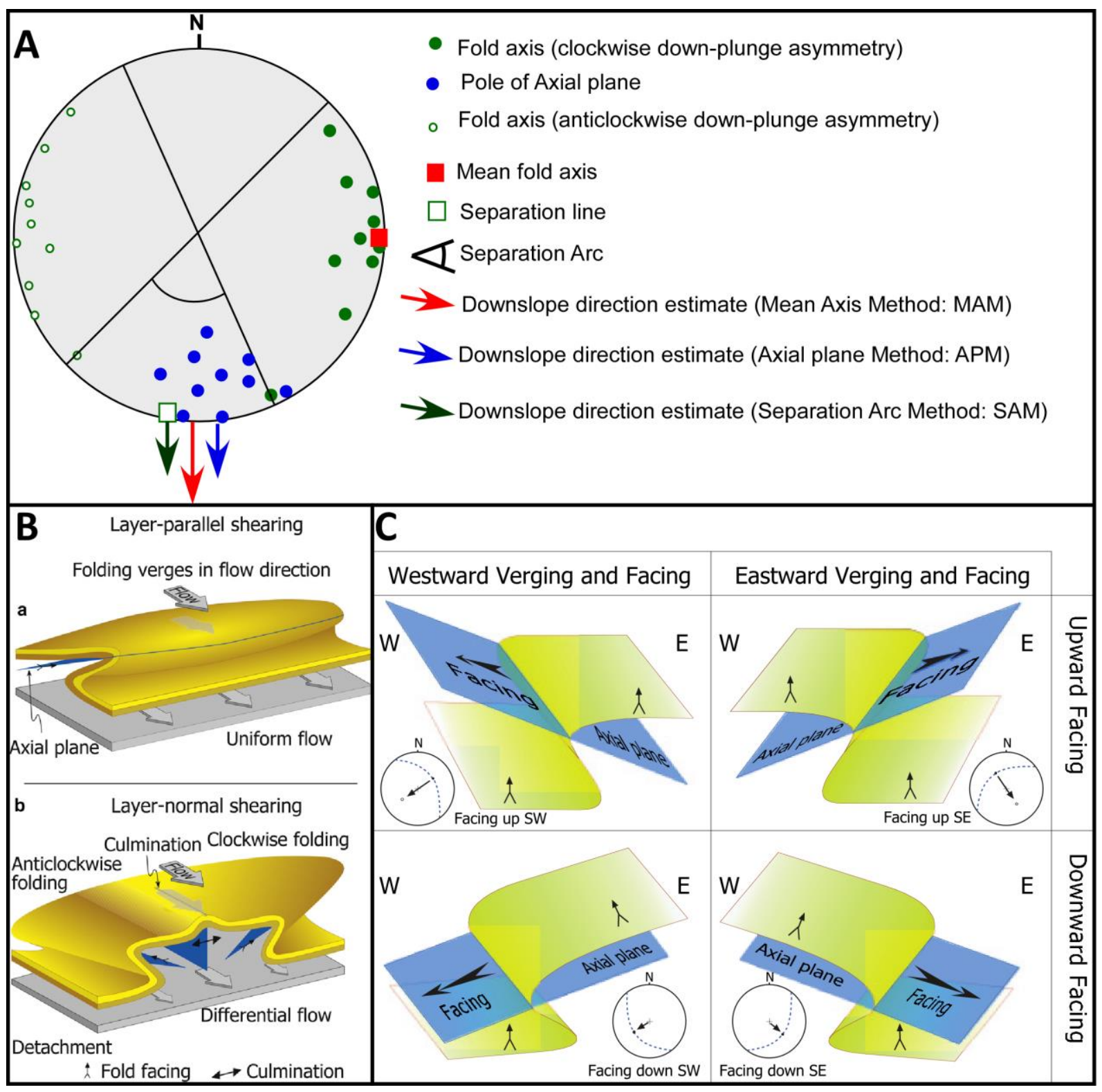




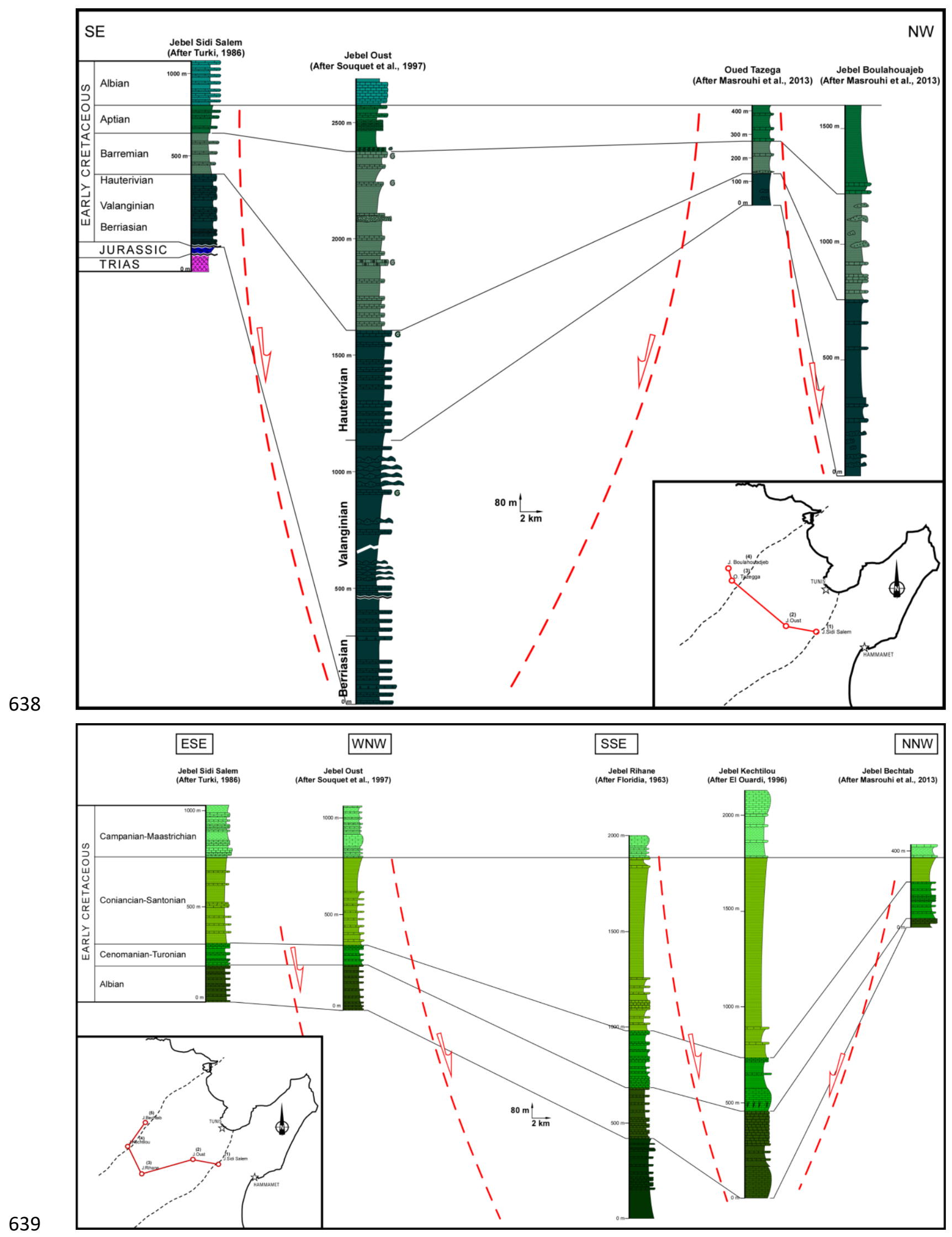








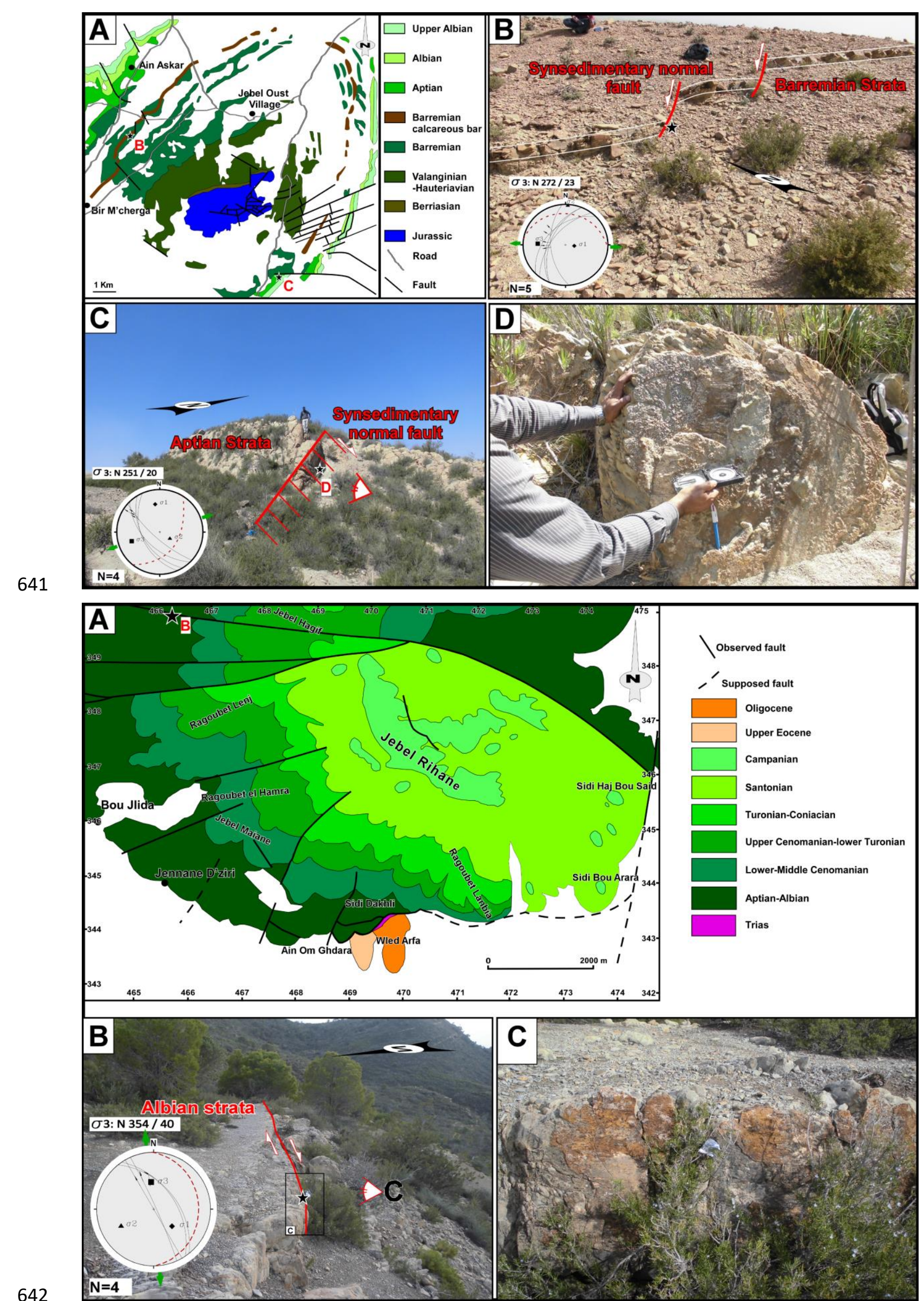


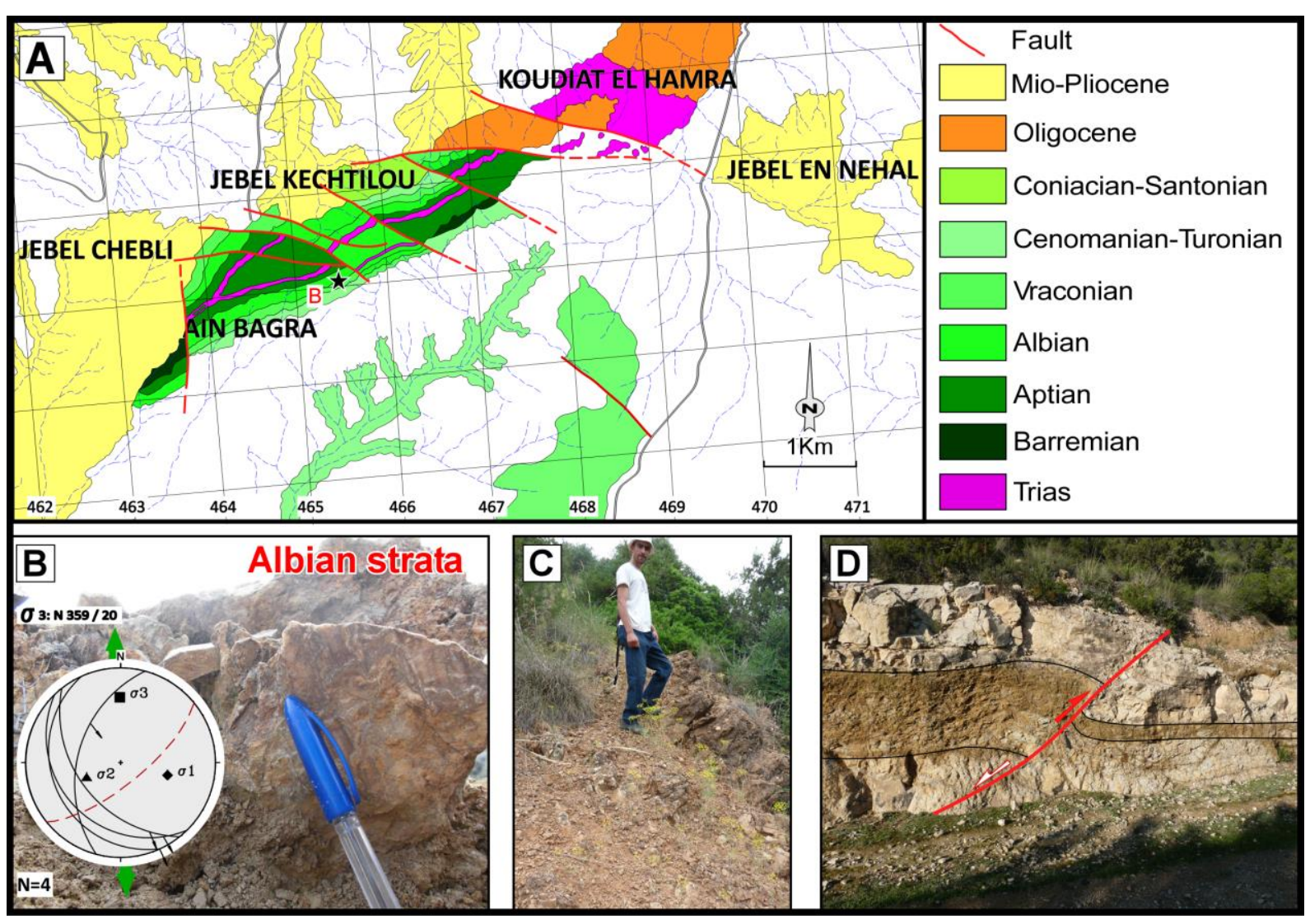

643

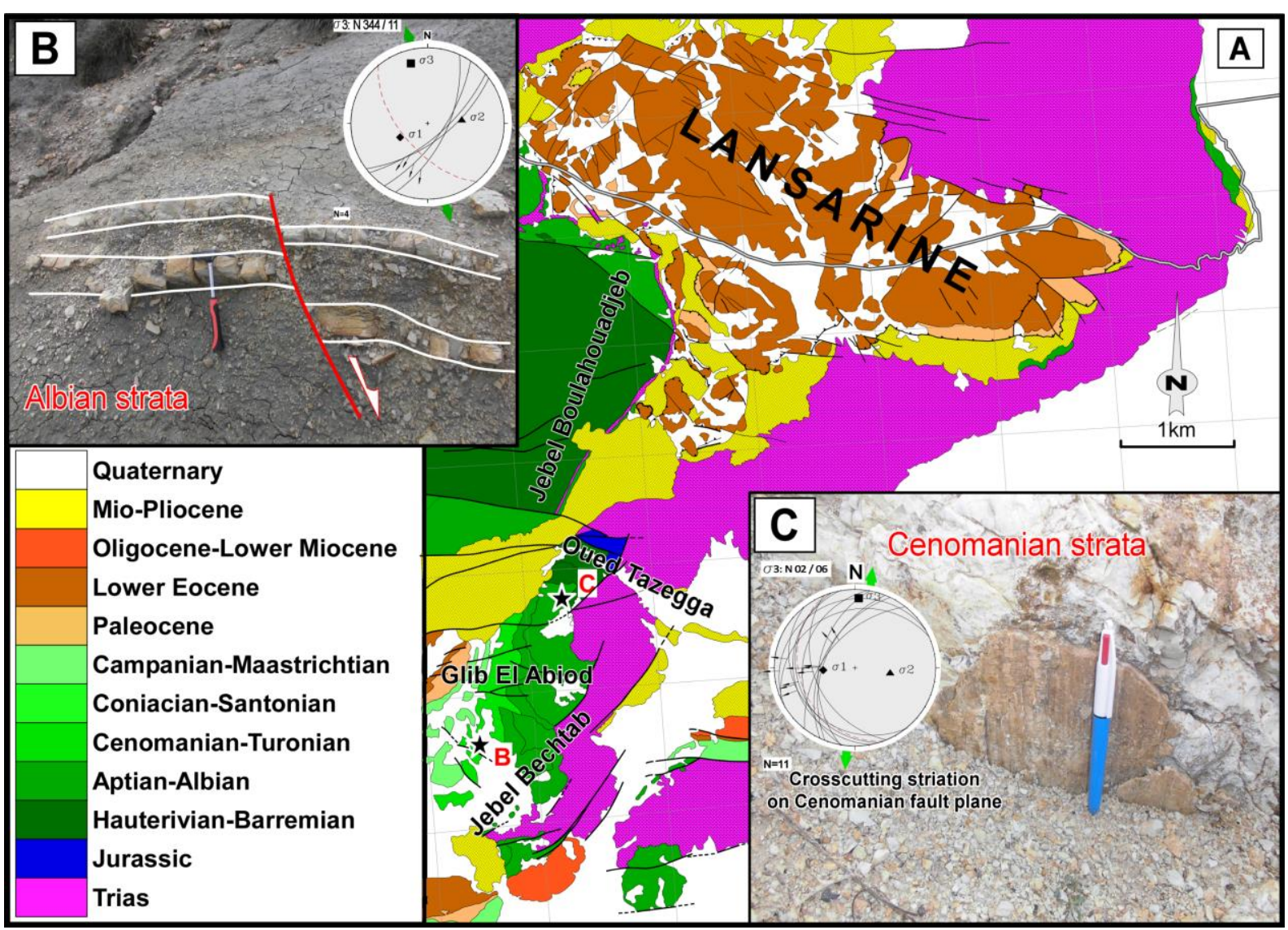




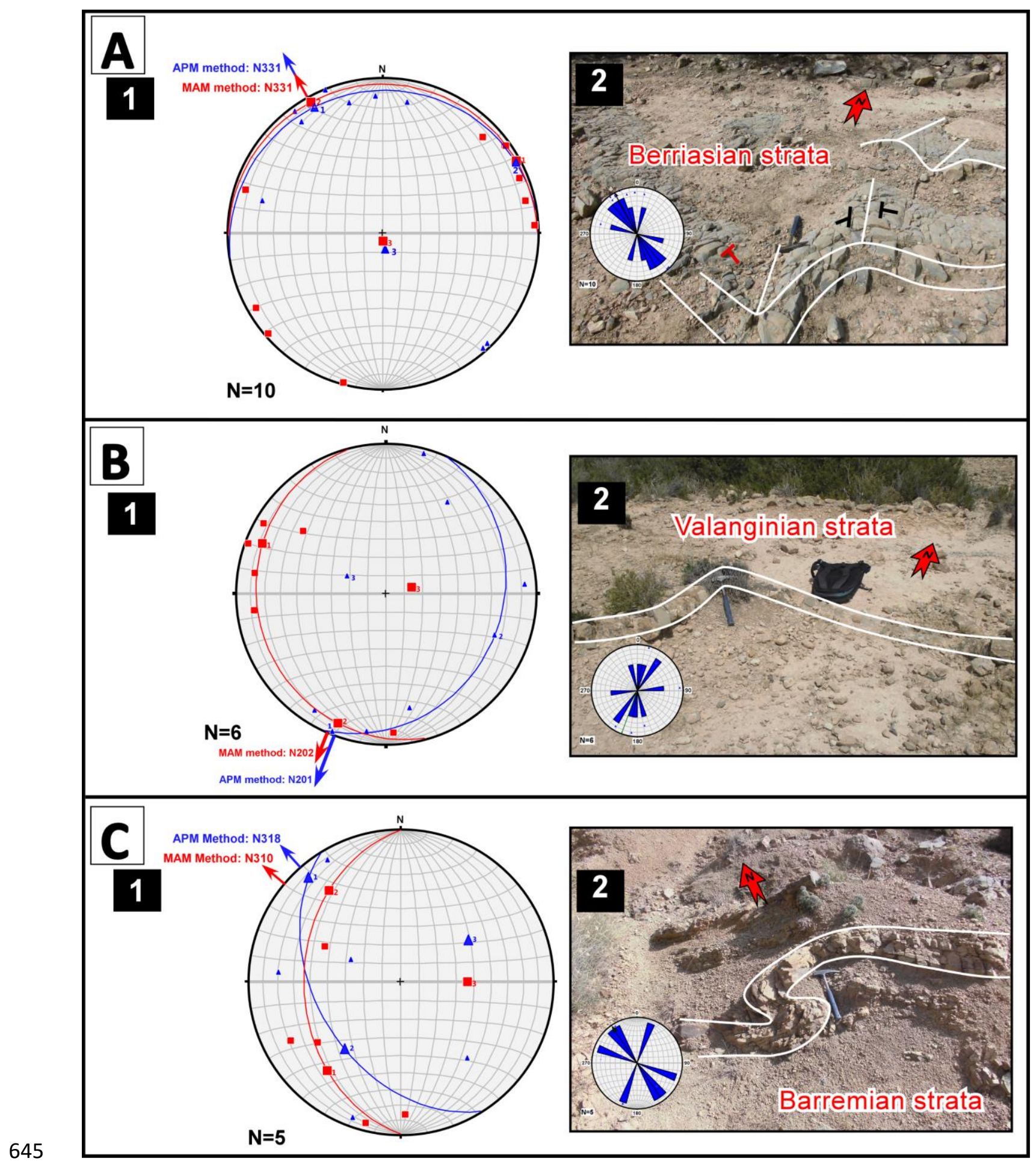




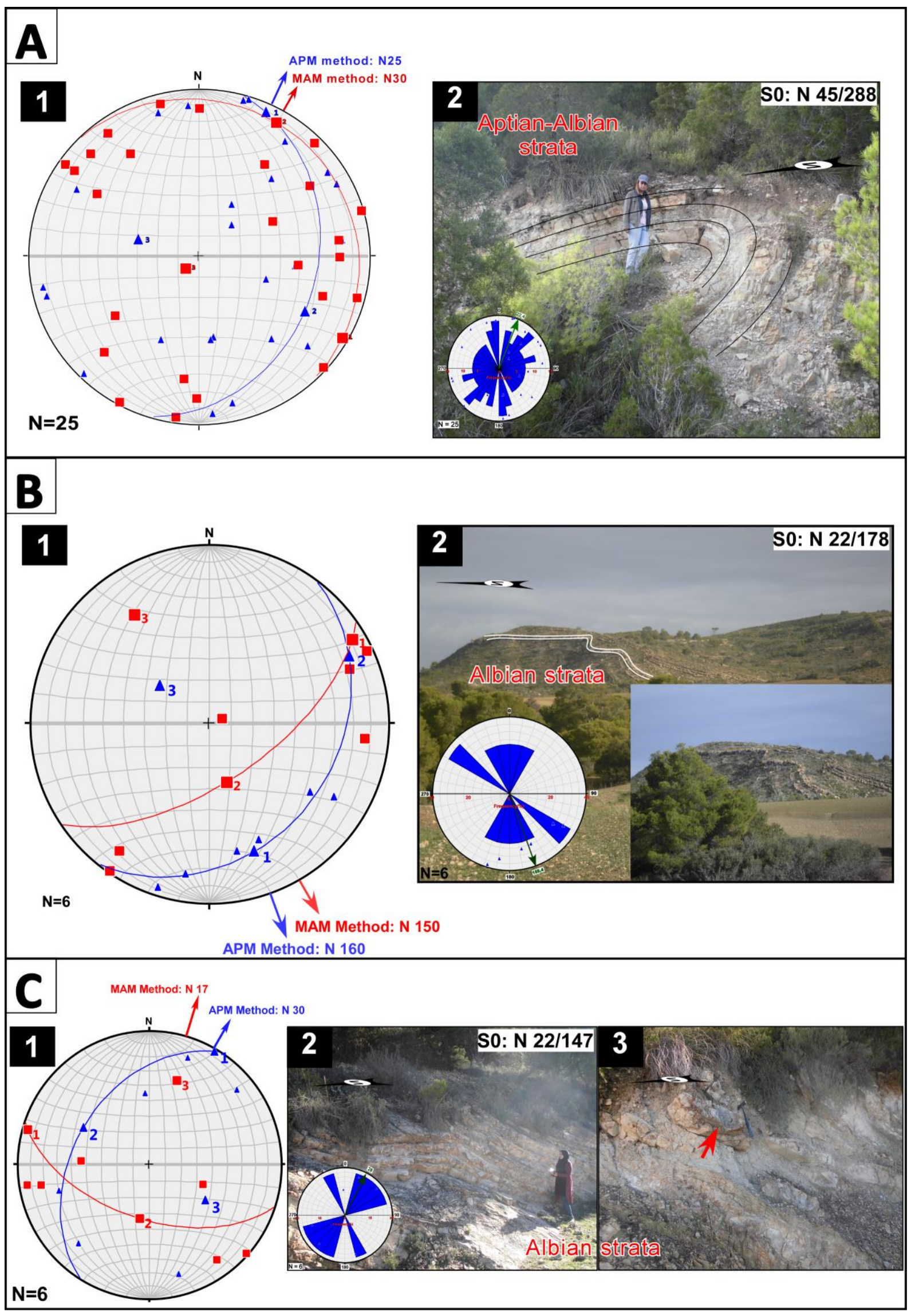




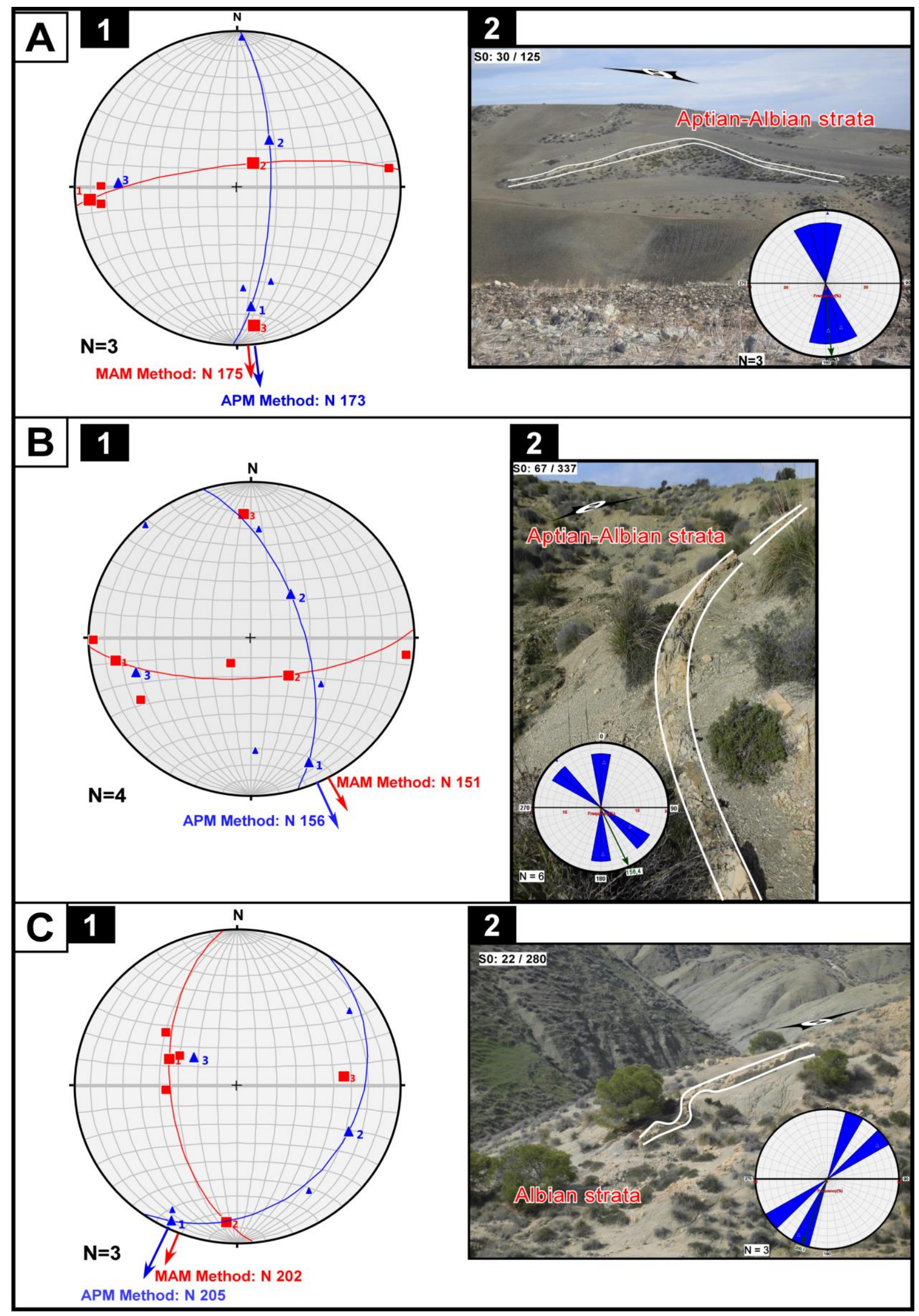




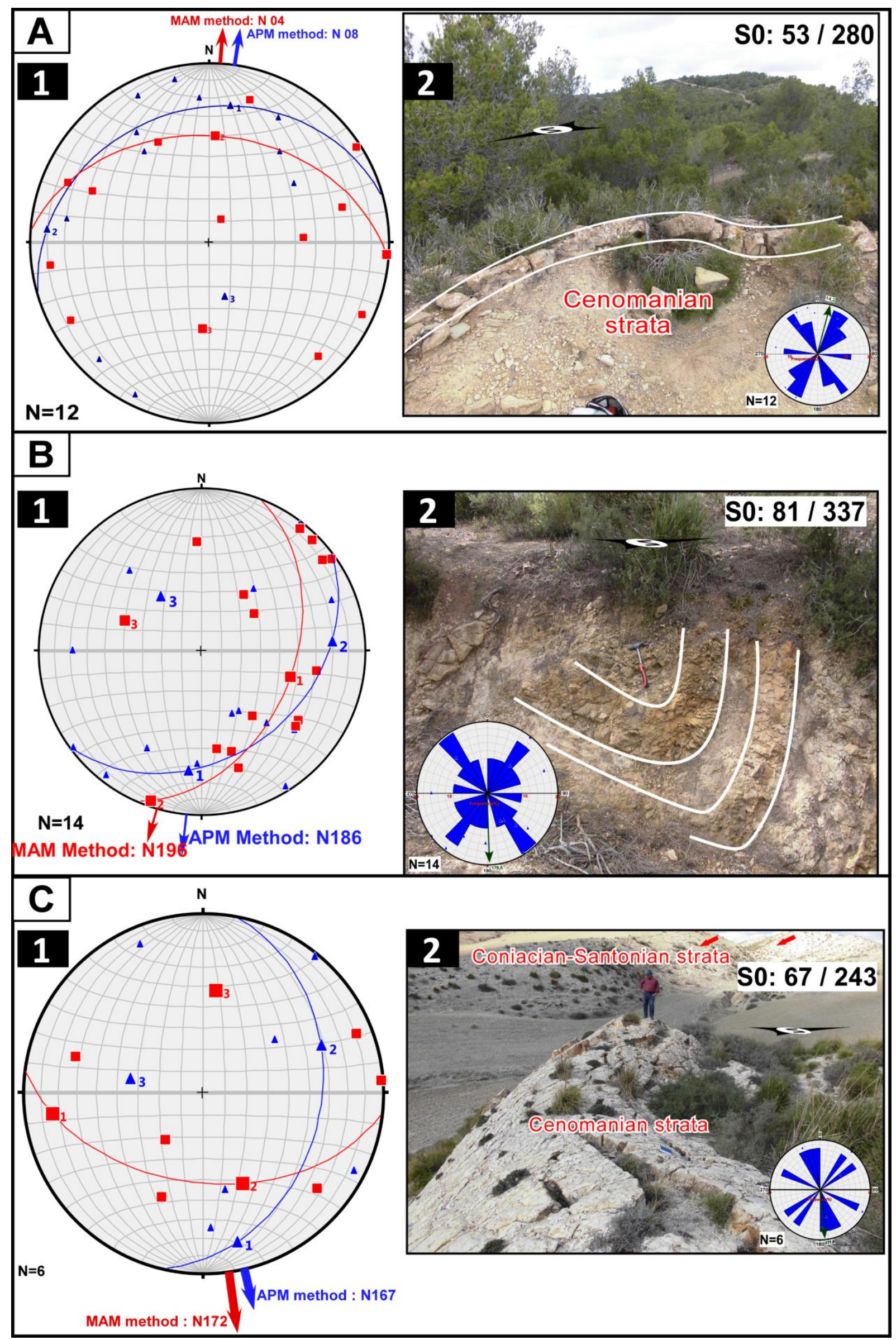




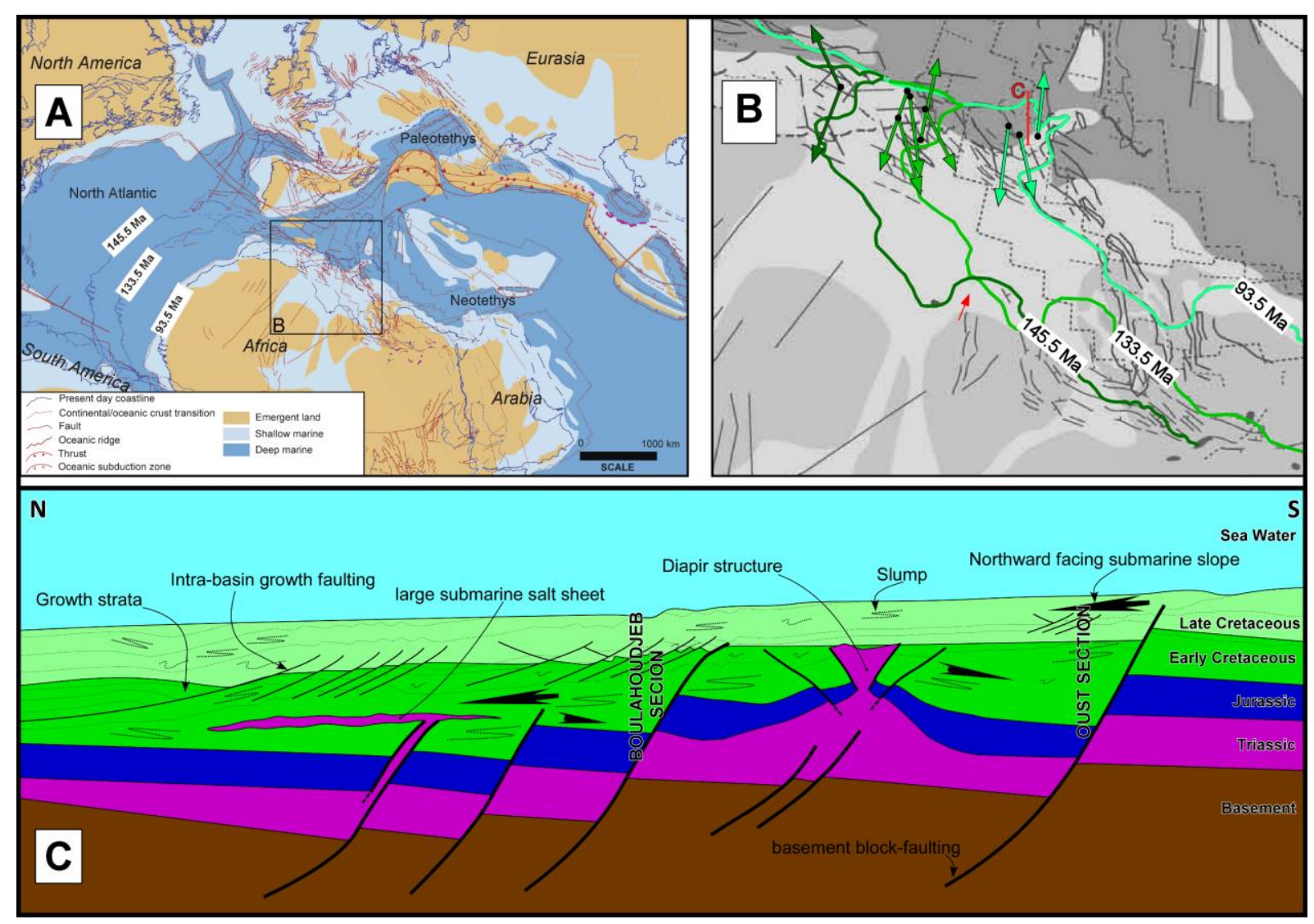

